\title{
Empirical Evidence Of Oil Price Shocks And Oil Economy Asymmetric Nexus: The Cases of Angola And Nigeria
}

\author{
Adedeji Abdulkabir Niran \\ Department of Economics, \\ University of Maiduguri, Borno, Nigeria \\ Ahmed Funmilola Fausat \\ Department of Economics, \\ University of Maiduguri, Maiduguri, Nigeria \\ Muhammed Musa \\ Department of Economics, \\ University of Maiduguri, Maiduguri, Nigeria
}

\begin{abstract}
The relationship between oil price shocks and economic growth (GDP) examined in many studies is assumed to be linear. However, this may incorrectly specify if the relationship is nonlinear. The few existing studies that modelled the relationship in dynamic form focused on developed oil-exporting or importing countries leaving dearth of studies on developing oil-backed countries whose oil price fluctuations may be more pronounced. Thus, this study examines asymmetric effects of oil price shocks on economic growth, focusing on Angola and Nigeria. We applied Nonlinear ARDL method to capture both the long- and short-run asymmetric effects with nonlinear error correction in a single equation. GDP and West Texas Intermediate (WTI) and Brent (BRT) oil prices data of 1980-2015 were employed and analyzed. Our results revealed that oil price-growth nexus for Angola and Nigeria is asymmetric. We found that oil prices have significant impacts with positive and negative effects on Nigerian economy, while only negative impact turns to be significant for Angola. Nonetheless, application of expansionary monetary policy for stabilizing these economies to support oil revenue in the wake of oil price fall may have little effect.
\end{abstract}

Keywords: oil price, economic growth, asymmetric effects, Nonlinear ARDL

\section{INTRODUCTION}

Studies have examined economic consequences of oil price (OILP) shocks from different perspectives particularly on macroeconomic indicators including its effect on Gross Domestic Product (GDP) growth (Law et al. [28], exchange rate (Kabiru et al. [24]), inflation (Salisu et al. [46]; Ibrahim and Chancharoenchai [19], unemployment (Dogrul and Soytas [11], and consumer prices (Ibrahim and Chancharoenchai [19]; Choudhry et al. [10]). The examinations extensively covered many major and non-major oil-exporting and importing economies. Generally, a common dominance of the views in these studies is that oil-exporting countries are vulnerable to oil price shocks resulting in unstable and unchartered economies (Mohaddes and Pesaran [30]). Also, most of these studies focused on non-major oil-exporting countries (Kabiru et al. [24]; Dogrul and Soytas, [11]; Andreopoulos [2], or mixed net oil-exporters and non-net oil exporters (Salisu et al. [46], Ibrahim and Chanchaoroenchai, [19]; among many others). Though, many of these studies demonstrated that the relationship between oil price and economic growth is linear, only few assumed it is nonlinear. However, the nonlinearity is often, typically, confined to ECM in particular which did not coherently capture long-run 
relationship and error correction mechanism, turning empirical attention to modelling the relationship in more dynamic form. More so, traditional cointegration methods (Engle-Granger and OLS) are not only seen to weakly capture endogeneity and serially correlated errors, but seen also to poorly detect asymmetric relations if they exist between variables. In addition, in oil price-growth literature, attention mostly focused on developed oil-exporting or -importing countries which leaves dearth of studies on developing countries whose oil price fluctuations may be more pronounced.

The current fall in OILP reopens the arguments on negative impact of the hydrocarbon on oildependent economies, but this issue somehow appears controversial. For instance, the downside of the OILP slump seem to have no reprehensible effect on high-income oildependent economies, like Saudi Arabia and Iran (IMF [20]) which simply reinvented economic policies to suit oil price slump. However, it played important role in driving recessions on low-income counterparts. For instance, this more likely, made Nigeria to devalue her currency and redefined oil policies aimed at cushioning the effect of oil price slump. The distortionary effect of OILP is one of the concerns of stakeholders and practitioners in resource-rich countries, as such, closely focus on its movements.

Analysis of the of oil price-economy nexus will, indeed, be more comprehensively understood when investigation is extended to developing net oil producers, particularly those members of the Organization of the Petroleum Exporting Countries (OPEC). This is because oil price serves as main determinant of these members' economies and on which oil price fluctuations may have significant implications. OPEC, being a key player in international oil market, often interferes in oil market with the aim of securing fair and stable prices for petroleum producers and achieving greater national control and socio-economic development for its member countries (Ovadia [38]). As often perceived, OPEC member countries' economies severely suffer from oil price downside shock. Due to fall in oil price, for instance, it is claimed that OPEC member countries lost about US $\$ 1$ trillion (IMF [20]). However, the effects appear not overtly have equal negative impact on all the members' economies as gross domestic product of some members (for example OPEC high-income countries such Saudi Arabia and Iran) are projected to rise even at dwindling oil price. Though the OPEC members consist of developed and developing countries, if oil price falls, it mostly affects oil-exporting developing countries. Is this true to OPEC developing countries? In other words, does the impact of oil price slump vary among OPEC members? More specifically, to what extent does devaluation of currencies embarked upon by some OPEC member countries revamp their economic growths in the wake of oil price fall? Thus, this study examines the response of two major OPEC member countries' economies (Nigeria and Angola) to oil price fluctuations, with focus on in attempt to provide answers to these questions.

This paper contributes to literature in three aspects. First, it provides new evidence that sheds light on the impact of oil price shocks on growth. Specifically, it explores whether there exists asymmetric effects in the OILP-growth relationship. Second, if there is clear evidence that oil price and economic growth are cointegrated, and that cointegration over shifting-regimes is significantly different, then previous linear model specifications for oil price shocks may have been wrongly specified. This is because if negative ranges of the relationship differ, in absolute impact, compared to positive ranges, linear model cannot capture such dynamic relationships, but this can be accommodated in a nonlinear model. Third, the findings of the present study may be helpful in policy making to accommodate dwindling effect of oil price on economy. This will minimize negative shock and such action would strengthen the economy. 


\section{OIL PRICE HYPOTHETICAL BEHAVIOR}

Oil price shocks is commonly seen to have two-side behavioral effects; the down-trend behavioral effect, which is argued to be reprehensible to oil-exporting countries and good to oil-importing countries; and the soar-trend behavioral effect, which is argued to have opposite effect to two oil-trading countries.

Ovadia [38] observed that there is co-movement between oil price and economic growth in the analysis of oil-effect on major oil-exporting countries, and even oil-exploring, for instance of Angola, Nigeria and Ghana. He opined that oil revenue is a strong determinant of growth of oilreliant economies for social and economic development. Thus, oil price shock may lead to slow economic growth. Similarly, as discussed by Mohaddes and Pesaran [30], oil price downtrend effect is more likely to have negative impact on economic growth in major oil producers' countries as they hugely loose revenues during the dwindle period; and as such they reimburse their loss of revenues by raising supplies. However, there is mixed view on the influence of oil price changes on exchange rate (Benassy-Quere et al., [6]). Apart from others factors, Ibrahim and Chanchaoroenchai [19] admitted that oil price fluctuations may influence depreciation of domestic exchange rate and they recommended that if an economy is oil dependent, depreciation may enhance economic growth. However, Aliyu and Tijjani [3] view was contrary to this preposition. They viewed that devaluation of domestic currency in the wake of oil price fall may not cushion the negative influence of the unfavorable oil price.

Also, the effect of oil price on unemployment is widely spread in literature. Focusing on efficiency of wage model, Kin et al. [27] observed that the decrease in the price of oil leads to decrease in price level and thus increase in real wage which consequently rises unemployment rate. Theoretically, an oil price-decreased shock often downsizes oil-dependent economy. This mostly reduces government's revenues and expenditure, the consequent of which will affect the economic activities in the country. This often leads government to increase taxes, and/or borrow to finance its portfolios. However, such action decreases production, increases unemployment rate and, consequently, slows down economic growth (Dogrul and Soytas [11]. Thus, employment rate in oil-exporting economy may be linearly related to oil price. Similarly, most oil-exporting countries are prone to inflation shock, though the level may differ on the economy of each OPEC member country. For instance, a fall in price of oil may likely influence governments' decisions to increase taxes and interest rates as alternative means of generating income. The action which may increase cost of production and consequent general high price in the economy.

\section{THEORETICAL AND EMPIRICAL REVIEWS}

Many studies had contributed to literature over the impact of variations of oil price on macroeconomic indicators of which they either focused on supply side (oil-exporting) or demand side (oil-importing) (Salisu et al. [46]; Ibrahim and Chancharoenchai [19]; Ewing and Thompson [14]; Nikbakht [34]; Brown and Yucel [7]). Particularly, the impact of oil price on GDP of oil-reliant economies is widely recognized owing to its contribution to oil economy, especially developing economies. Nigeria and Angola are among net oil-exporting countries whose economies are indeed heavily depend on petroleum resources. For instance, both in Angola and Nigeria, crude oil exports accounts for over 80 percent of government's annual revenue, and GDP of the duo from crude oil accounting for over 40\% (Adedeji et al. [1] Ovadia, [39]; [40]). The foreign earnings realized are used to sustain their economies in order to foster physical, political and social developments. The global oil prices which plummeted to less than US $\$ 40$ per barrel in the last quarter of 2015 (IMF [20]) unleashed an external shock on Angolan and Nigerian economies. For instance, oil receipt in Nigeria in 2016 amounted to about US $\$ 27$ billion (OPEC [36]). This figure is far below what the country earned in the 
previous years. However, fall in the revenue has been attributed to fall in the price of crude oil in the international market (CBN [9]).

Nagmi et al. [32] opined that oil prices are volatile in nature and this has implications on the performance of (macroeconomic variables) economic growth and development, posing great challenges for policymaking. The author claimed that transmission mechanisms through which oil prices influence real economic activity include both supply and demand channels. The supply side effects are related to the fact that crude oil is a basic input to production and consequently an increase in oil price leads to a rise in production costs that induce firms to lower output. Oil price changes also entail demand side effects on consumption and investment. Thus, the impact which oil price volatility could have on economy largely depends on the ruling market price of oil. The Nigerian economy uniquely qualifies as both an oil exporting and importing economy since she exports crude oil and also imports refined petroleum products. However, her production is far above consumption. (EIA [12])

An increase in oil production and price helps boost economic growth in the oil-exporting countries. Many of these countries may also benefit from the spillover-effects on trade, tourism, and financial inflows. Ghalayini [16] observed that the recent sharp decline in world oil prices combined with OPEC-imposed production cuts, decline in oil demand due to discovery of shale oil, as alternative energy, and reduced capital inflows slowed economic growth of many developing oil-wealth countries. However, the case is not same for developed oil-economies, like Saudi Arabia, Iran, and United Arab Emirates, whose growths, as predicted, would not overtly be affected when there is negative shock (IMF [20]). As IMF [20] highlighted, this may either be due to economies' diversification strategies these countries employed or policies implemented that accommodate negative shock or both, help to keep their GDP from being "disequilibrated". This, obviously, is not the case for developing economies as sharp drop in oil prices nosedived the economy with resultant effects on macroeconomic activities that support growth and sustainable development.

Gunu et al. [17] opined that oil prices have been highly volatile since the end of World War II and becomes even more serious in recent time. This has implications for the economies of oil exporting countries, particularly oil dependent countries like Nigeria. Using VAR, the paper examined the impact of these fluctuations on four macroeconomic of Nigeria. The results showed that oil prices have significant impact on real GDP, money supply and unemployment. Its impact on the fourth variable, consumer price index was not significant. This implies that three key macroeconomic variables in Nigeria significantly explained the exogenous and the highly volatile variable. Hence, the economy is vulnerable to external shocks. Consequently, the macroeconomic performance will be volatile and its management indeed very difficult.

Oyeyemi [37] also observed that oil prices, traditionally have been more volatile than many other commodity or asset prices since World War II and had a lot implications on major macroeconomic variables such as inflation, money supply, capacity utilization and economic growth to mention a few. The paper investigated the growth implications of crude oil price shock in Nigeria. Empirical analysis was conducted by employing multiple regression technique to the annual data on Nigeria economy for the period 1979-2010. The findings revealed that the shock in the price of crude oil in the global oil market that period produced a long-term effect on economic growth in Nigeria.

Ismail [22] examined the impact of oil price shocks and their transmission channels to selected macroeconomic variables (trade balance, inflation, government revenue and exchange rate) which serve as proxies for economic activities in Nigeria using quarterly data from 1980Q1 to 
2011Q4. Empirical analysis was carried out using VAR framework. Further the Impulse Response Function (IRF) and the Variance Decomposition (VDC) were carried out to trace the impact of oil shocks to the Nigerian economy. The result showed that oil price shocks have negative impact on nearly all the variables used in the analysis; furthermore the asymmetric relationship between oil price shocks and GDP was not established as the effects was found to be minimal in all the tests results. The result clearly illustrated that oil price decreases affect most of the macroeconomic indicators.

In their research, Alley et al. [4] examined the effect oil price on the Nigerian economy for the period 1981-2012. This research showed that shocks in oil price insignificantly impedes economic growth, hence oil price changes impact was negative. The significant positive effect of oil prices on economic growth stresses the conventional wisdom that the high oil prices are beneficial to the oil-exporting country like Nigeria. However, the oil price shocks created undermining and uncertain effective fiscal management of oil revenues. This, indeed, has been the hallmark of Nigerian economy till date.

Caldara et al. [8] observed that shock in oil supply account for 50 percent of oil prices fluctuation, and shock in demand only account for 30 percent in changes of oil price. They stressed that lower oil prices driven by supply shocks depressed economic performance in oilexporting economies, while it boosts economic activity in oil-importing economies. Thus, this helps explaining the muted effects of oil price changes on global economic activity. They also found the selection of oil market elasticity essential to understanding the nature of oil price volatility and to measuring the size of the complications of oil price on economic activity.

Empirically, the impact of changes in oil price on economic growth as observed by previous studies assumed linear adjustment exists between the two variables. For example, results from studies by He, Wang and Lai [18], Sayed [47], Rafiq, Salim and Bloch [44], Lescaroux and Mignon [29] and Lardic and Mignon [27] found linear and positive relationships between oil price and economic growth. More recently, studies, such as Oladosu, Leiby, Bowman, UríaMartínez, and Johnson [35], Ishmael, Rivi and Idisi [21], Gunmi, Buhari and Muhammad [16], Ratti and. Vespignani [45], Monesa and Qazi [31] also found similar evidence. Although, Gadea, Gomez-Loscos and Montanes [15] and Jawa [23] could not establish linear significant effects of changes in oil prices on economic growth for the economies' studies. Many these studies focused on Non-OPEC countries whose economies are not fully depent on oil, and on which changes in oil prices may not have a significant influence. A few studies that focused on OPEC member countries such as Monesa and Qazi [31] who examined the impacts of oil prices on economic growth of selected OPEC: Algeria, Iran, Kuwait, Saudi Arabia, Nigeria and Venezuela; found mixed results.

A common assumption of these studies is that the relationship between economic growth and oil price is linear. This assumption is based on using standard linear models (for example, ECM, Granger causality, VAR) as well as the standard unit roots (Augmented Dickey-Fuller, ADF) and cointegration analysis (Engel-Granger, and Johensen and Juselius cointegration). Enders and Siklos [13] however noted that such assumption may be misleading since it tends to result in model misspecification if the actual relations are non-linear. This assertion also recently supported by Shin, Yu, and Greenwood-Nimmo. [49] as they recognized that key macroeconomic variables tend to response differently (nonlinear) to different regimes, and such assumption may lead to wrong policy prescription if economy reacts asymmetrically over oil price positive-negative changes. More so, traditional cointegration methods have been seen to weakly capture endogeneity and serially correlated errors, and seen also to poorly detect nonlinear (asymmetric) relations if they exist between variables. In addition, the attention of 
many these studies mostly focused on developed oil-exporting or -importing countries which leaves dearth of studies on developing countries whose oil price fluctuations may be more pronounced.

Based on the context described above, it is however from literature difficult to draw a conclusion about the effect of oil price shock on economic growth. The relationship between the variables needs to be further explored by applying nonlinear approach which this study addressed in the subsequent sections.

\section{Nonlinear ARDL Cointegration Framework}

The recently developed Nonlinear Autoregressive Distributed Lag (NARDL) model is applied in this paper. Common nonlinear modelling in the context of cointegrating long-run typically confined to the error correction mechanism (ECM) procedure is based on either the threshold ECM associated with Balke and Fomby [5], or the Markov-Switching ECM of Psaradakis et al. [43], or the smooth transition regression ECM developed by Kapetanios et al., [25]. The strength of ECM method often relies on the assumption that the underlying cointegrating relationship between variables is linear. This reads that the positive and negative impact of a regime shift on independent variable is similar on dependent variable. However, this may be excessively restrictive in the case where the assumption does not hold (Schorderet, [48]; Shin et al., [49]). For this important limitation of ECM, dynamic (asymmetric) threshold has been suggested to explore underlying relationship among macroeconomic variables. NARDL is a new technique for detecting nonlinearities focusing on the long and short-run asymmetries among the macroeconomic variables. NADL technique was advanced by Shin et al. [49], an extended version of the linear ARDL into a dynamic model. Thus, the model is refined with ability to capture nonlinearities and error correction mechanism as it can separately discern positive and negative contingency effects and robustness of the stochastic behavior of the variables.

Shin et al. [49], argued that the direction of asymmetry may switch between the short-run and the long-run, emphasizing that a positive shock may have a larger absolute effect in the shortrun while a negative shock may have a larger absolute effect in the long-run (or vice-versa). The simplicity and flexibility of NARDL framework capture such complex phenomena. In Shin et al.'s [49] specification, an extractive series from Pesaran and Shin (41), Pesaran et al. (42), and Schorderet [48], nonlinear asymmetric cointegrating model was written as:

$$
y_{t}=\beta^{+} x_{t}^{+}+\beta^{-} x_{t}^{-}+\mu_{t}
$$

where $\beta^{+}$and $\beta^{-}$are the associated long-run parameters, $y_{t}$ and $x_{t}$ are scalar variables, assumed to be stationary at first difference, I(1), $x_{t}$ are $k \times 1$ vector of regressors decomposed into positive and negative partial sum processes: $x_{0}+x_{t}^{+}+x_{t}^{-}$and $\mu_{t}$ is independent distributed disturbance with id process with zero means and constant variance. The partial sum processes are defined as follows:

$$
\begin{aligned}
& x_{t}^{+}=\sum_{j=1}^{t} \Delta x_{t}^{+}=\sum_{j=1}^{t} \max \left(\Delta x_{j}, \bar{x}\right) \\
& x_{t}^{-}=\sum_{j=1}^{t} \Delta x_{t}^{-}=\sum_{j=1}^{t} \max \left(\Delta x_{j}, \bar{x}\right)
\end{aligned}
$$


where the $\Delta x_{t}$, in Eq. 2 and 3, are changes: above, positive process $(+)$, and below, negative process $(-)$, the threshold of exogenous variable $\left(x_{t}\right)$, which delineates the positive and negative shocks. The asymmetric threshold in these equations is set equal to the mean of first differenced series of the exogenous variable. As Shin et al. [49] recommended, the mean of the first differenced of exogenous variable, is sufficient to measure the swift of both regimes from equilibrium and determine the speed of adjustment of the variable.

In determining the speed of adjustment in asymmetric or nonlinear case, based on Shin et al. [49] derivation, asymmetric error correction model (AECM) is derived by associating Eq. 1 with the conventional ARDL(p, q). The model is written as:

$$
\Delta y_{t}=\rho y_{t-1}+\lambda^{+} x_{t-1}^{+}+\lambda^{-} x_{t-1}^{-}+\sum_{j=1}^{p} \theta_{j} \rho y_{t-1}+\sum_{j=0}^{q}\left(\mathrm{Z}^{+}+\mathrm{Z}^{-}\right)+e_{t}
$$

where: $\mathrm{Z}^{+}=\pi_{j}^{+} \Delta x_{t-1}^{+} ; \mathrm{Z}^{-}=\pi_{j}^{-} \Delta x_{t-1}^{-}$, for $\mathrm{j}=1 \ldots \mathrm{q} ;$ and $\lambda^{+}=-\rho \beta^{+} ; \lambda^{-}=-\rho \beta^{-}$.

The estimation procedure of this analysis follows four steps. First, estimation of Eq. 4 by using standard ordinary least square (OLS). Second, establishment of the long-run relationship between the levels of the dependent variable, $y_{t}$, and independent variables: $x_{t}^{+} ; x_{t}^{-}$, by means of a modified $F$-test, through a bound test approach with join null hypothesis that $\rho=\lambda^{+}=$ $\lambda^{-}=0$. Third, using the Wald test for testing whether long-run symmetric relation exists among the variables with hypothesis that $\lambda^{+}=\lambda^{-}$, and short-run symmetric with hypothesis that $\pi_{j}^{+}=\pi_{j}^{-}$. Fourth, in this step, asymmetric of nonlinear ARDL model is estimated (Eq. 4) for detecting whether dynamic multiplier effects of a unit change in decomposed exogenous variable; $x^{+}$and $x^{-}$; on dependent variable, $y_{t}$. Shin et al. [49] recently developed a technique for deriving all the four steps in one estimation in which asymmetric long-run coefficients are calculated as $\beta^{+}=-\lambda^{+} / \rho$ and $\beta^{-}=-\lambda^{-} / \rho$, which we applied in this paper.

\section{Variable, Data and Model}

This paper focuses on Nigerian and Angolan economies' responses to changes in oil price shocks as case study in estimating oil prices asymmetric effects on oil-reliant economy. These countries net oil-exporting members of OPEC, whose oil contributes large share to their economies. The variables employed in this paper are Gross Domestic Product (GDP) growth used as a measure of economy, based on constant 2010 U.S. dollars. The oil price data are both Brent and West Texas Intermediate (WTI) measured as U.S. dollars market prices per barrel of crude oil. The annual data used for analysis covered 36 periods, 1980 to 2016. The GDP data were collected from the World Development Indicators (WDI) database, while West Texas Intermediate (WTI) and Brent (BRT) oil prices data were collected from British Petroleum database. The WTI and BRT oil prices were considered for insinuation that both are traded market prices that were determined by the market and to allow for comparison. All variables are expressed in level form.

The empirical analysis is performed on the following explicit model:

$$
G D P_{t}=f(W T I, B R T)
$$

and further decomposed as:

$$
G D P_{t}=f\left(W T I_{-o i l p t}^{+}, W T I_{- \text {oilpt }}^{-}, B R T_{- \text {oilpt }}^{+}, B R T_{- \text {oilpt }}^{-}\right)
$$


where $W T I_{-o i l p t}^{+}, W T I_{-o i l p t}^{-}, B R T_{-o i l p t}^{+}, B R T_{- \text {oilpt }}^{-}$are decomposition series of positive and negative changes in WTI and BRT oil prices, respectively. Following Shin et al. [49], asymmetric nonlinear model in this paper is written as:

$$
\begin{aligned}
& \Delta G D P_{t}=\alpha+\rho G D P_{t-1}+\lambda_{1}^{+} W T I_{-o i l p, t-1}^{+}+\lambda_{1}^{-} W T I_{-o i l p, t-1}^{-}+\lambda_{2}^{+} B R T_{-o i l p, t-1}^{+} \\
& +\lambda_{2}^{-} B R T_{-o i l p, t-1}^{-}+\sum_{j=0}^{q} \theta_{i} G D P_{t-1}+\sum_{j=0}^{q} \pi_{1}^{+} \Delta \mathrm{WTI}_{-o i l p, t-1}^{+}+\sum_{j=0} \pi_{1}^{-} \Delta W T I_{-o i l p, t-1}^{-} \\
& +\sum_{j=0}^{q} \pi_{2}^{+} \Delta \mathrm{BRT}_{-o i l p, t-1}^{+}+\sum_{j=0}^{q} \pi_{2}^{-} \Delta \mathrm{BRT}_{-o i l p, t-1}^{-}+e_{t}
\end{aligned}
$$

A null hypothesis of no cointegration, i.e. the coefficients of the lagged level variables are jointly equal to zero, is first tested. Non-rejection of this hypothesis will indicate nonexistence of long-run relationship among the variables which will allow to proceed to test asymmetric cointegration, by estimating the nonlinear error correction model of the Eq. 7. We include 6 lag length $(p, q)$ in the model and, following the general-to-specific approach, we retained only the significant lags in order to obtain parsimonious dynamic multipliers of NARDL specification.

\section{DESCRIPTIVE STATISTICS AND RESULTS}

Table 1 presents descriptive statistics. On average, the annual percentage growth rates of GDP for Nigeria and Angola are about 25.9\% and 24.4\%, respectively, considering the value of the mean over the periods studied. The values are considerably relatively high. This is not surprising as it has been observed that net oil-exporting countries (the biggest oil producers within OPEC) often much have interest to protect their market shares rather than price, as they usually pay much attention to increase supply which might have a spin-off effect on their economic growths. The BRT and WTI crude oil prices are, on average, \$41.65 and \$41.19, respectively. Though the range of two prices are close, and volatile, but BRT oil price appears more volatile than the WTI. Nonetheless, the two prices are used in this study for robustness purpose.

Table 1. Descriptive statistics

\begin{tabular}{lcllll}
\hline Variable & obs. & mean & std.dev. & min & $\max$ \\
\hline GDPA & 36 & 24.41 & 0.48 & 23.82 & 25.36 \\
GDPN & 36 & 25.93 & 0.49 & 25.34 & 26.86 \\
WTI_oilp & 36 & 41.19 & 27.79 & 14.39 & 100.06 \\
BRT_oilp & 36 & 41.65 & 31.10 & 12.72 & 111.67 \\
\hline GDPA denotes economic growth for Angola. GDPN &
\end{tabular}

We applied Augmented Dickey and Fuller (ADF) unit root test to ensure that the series used in this study are not $I(2)$ order of integration. The use of forms of ARDL model in cointegration testing allow either I(1) or combination of $I(0)$ and $I(1)$ stationarity order, however, inclusion of variables with $I(2)$ order under this method has been considered to render $F$-statistic value inconsistent (Katrakilidis and Trachanas, [26]. Table 2 presents our ADF results. All variables are found to be stationary in their first differenced series, I(1), which allows us to proceed with ARDL framework testing for cointegration of the variables. 
Table 2. Augmented Dickey-Fuller unit root tests

\begin{tabular}{|c|c|c|c|c|c|c|}
\hline \multirow[b]{2}{*}{ Series in levels } & \multicolumn{3}{|c|}{ Intercept without trend } & \multicolumn{3}{|c|}{ Intercept with trend } \\
\hline & $\begin{array}{l}\text { Test } \\
\text { statistic }\end{array}$ & $\mathrm{k}$ & $\begin{array}{l}\text { Critical } \\
\text { value }\end{array}$ & $\begin{array}{l}\text { Test } \\
\text { statistic }\end{array}$ & $\mathrm{k}$ & $\begin{array}{l}\text { Critical } \\
\text { value }\end{array}$ \\
\hline GDPA & -2.087 & 15 & -2.614 & -1.390 & 10 & -3.207 \\
\hline GDPN & $-3.590 * * *$ & 2 & -2.613 & -1.060 & 7 & -3.205 \\
\hline WTI_oilp & -1.355 & 1 & -2.613 & -2.193 & 1 & -3.205 \\
\hline BRT_oilp & -1.274 & 1 & -2.613 & -2.062 & 1 & -3.205 \\
\hline \multicolumn{7}{|l|}{$\Delta$ series } \\
\hline$\Delta \mathrm{GDPA}$ & $-3.705^{* *}$ & 13 & -3.012 & $-3.461^{* * *}$ & 14 & -3.269 \\
\hline$\Delta \mathrm{GDPN}^{\mathrm{N}}$ & $-3.898^{*}$ & 1 & -3.369 & $-5.625^{*}$ & 1 & -4.253 \\
\hline$\Delta$ WTI_oilp & $-5.554^{*}$ & 1 & -3.639 & $-5.377^{*}$ & 1 & -4.253 \\
\hline$\Delta$ BRT_oilp & $-4.484^{*}$ & 1 & -3.639 & $-4.295^{*}$ & 1 & -4.252 \\
\hline
\end{tabular}

Note: $\Delta$ denotes first difference. The optimal lag length for the ADF is chosen based on the Schwarz Info Criterion, while k denotes lag order. GDPA and GDPN ${ }^{\mathrm{N}}$ stand as defined in Table 1.

$*, * *$, and ${ }^{* * *}$ signify $1 \%, 5 \%$, and $10 \%$ significance levels, respectively.

Accordingly, we estimated Eq. 7 and applied the general-to-specific procedure to arrive at the model final specification. The preferred specification is chosen by grid search of better lags starting with max $\mathrm{p}=\max \mathrm{q}=6$ and specific lags $(\mathrm{p}=2, \mathrm{q}=4$ for Nigeria and $\mathrm{p}=4, \mathrm{q}=2$ for Angola) were finally used for the estimation. The dynamic asymmetric cointegration results for Nigeria and Angola are shown in Tables $3 a$ and 3b, respectively. Before examining the direction (sign) and sensitivity (size) of asymmetric effect, we test for the presence of this effect as to whether the positive and negative regimes of the underlying regressors are equal symmetric or asymmetric. If the null hypothesis is rejected, it indicates that there exists asymmetric effect, and that both positive and negative components of the underlying independent variable have different long and short-run equilibrium relationships between the positive and negative shocks with the dependent variable. The decision is based on the joint hypothesis that the coefficients of the lagged level variables are jointly equal to zero. In Table $3 \mathrm{a}$ and $3 \mathrm{~b}$ lower panel, the $F_{\text {-PASS }}$ coefficients (9.76 and 5.86), for Nigeria and Angola respectively, are found to be statistically significant, exceed the upper bound critical value taken from Narayan et al.,'s [33] critical value table simulated for bound test. This implies rejection of the hypothesis, indicating the existence of long-run co-movement relationship between the variables, and suggesting asymmetric nature of the relationship in the respective time horizon (long or shortrun). The presence of long and short-run asymmetries imply that the positive and negative shocks of the underlying regressors should be modeled separately as the shocks are likely to have different impact on the dependent variable. Hence, this finding allows us to proceed to first verify the appropriateness of the asymmetric model and then estimate the model, which is the focus of this paper.

The coefficients generated from the Wald tests for both long- (WLR) and short-run (WSR) symmetries are reported in the lower panel of Table 3a and 3b. The magnitudes suggest the rejection of the null hypothesis of short-run symmetry for Nigeria, long- and short-run symmetric for Angola, between the positive and negative components of each one of the examined variables. More specifically, the short-run coefficients for the WTI_oilp, and BRT_oilp, for Nigeria, the Wald tests are found to be 11.45 and 12.24, respectively, each significant at the better $5 \%$ and $1 \%$ levels, respectively. For Angola, the long-run coefficients for the WTI_oilp, and BRT_oilp, the Wald tests are found to be 11.88 and 10.98, respectively, each significant at 
the better $1 \%$ and $5 \%$ levels, respectively. These findings further support that a linear model for the oil prices shocks would be incorrectly specified.

Turning to the estimation of the long-run dynamics of the asymmetric ARDL model, primary focus of this paper, the estimated results for Nigeria and Angola were presented in Table 3a and $3 \mathrm{~b}$, respectively. The long run coefficients for positive oil prices $\left(L^{+}{ }_{w t i-o i l p}=2.41\right.$ and $L^{+}$brt-oilp $=2.10)$, and negative $\left(L^{-}{ }_{w t i-o i l p}=-2.21\right.$ and $\left.L^{-}{ }_{b r t-o i l p}=1.92\right)$, for Nigeria, are all statistically significant at 1\% and 5\% levels, respectively. Corresponding with the reports in many studies on oil-dependent economies, the pass-through of oil prices to such economies often complete. Based on our result, we may conclude that a $1 \%$ increase in the oil price may likely to lead to growth in Nigerian economy in the range of $2.10 \%$ to $2.41 \%$, while the country may experience economic downturn of in the range of 1.92 to $2.21 \%$ if the price slumps by $1 \%$, holding other factors constant. Based on this, we observe that oil price increase and decrease overtly have effects on Nigerian GDP. This supports the Ishmael, Rivi and Idisi [21] and Umar and Abdulhakeem [50] findings. Both regimes appear to have a strong influence on the country's budget as its budget is normally benchmarked at oil price. As the case may be, oil price increase may lead to budgetary surplus, which in turn may lead to economic growth; contrariwise, oil price decrease may lead to budgetary deficit, which consequently may add pressure to the economy. 
Table 3a. Dynamic Asymmetric Estimation of oil prices for Nigeria

\begin{tabular}{|c|c|c|c|c|c|}
\hline \multirow[b]{2}{*}{ Variable } & \multirow[b]{2}{*}{ Coefficient } & \multirow{2}{*}{$\begin{array}{c}\text { Standard } \\
\text { error }\end{array}$} & \multirow[b]{2}{*}{ T-ratio [Prob] } & \multicolumn{2}{|c|}{ 95\% Conf. interval } \\
\hline & & & & lower & upper \\
\hline Constant & 0.101 & 0.032 & $3.13[0.01]$ & 0.027 & 0.175 \\
\hline $\operatorname{lnGDP}(-1)$ & -2.388 & 0.368 & $-6.48[0.00]$ & -3.238 & -1.539 \\
\hline lnwti_oilp ${ }^{+}(-1)$ & 5.759 & 1.943 & $2.96[0.02]$ & 1.277 & 10.241 \\
\hline lnwti_oilp- $(-1)$ & 5.290 & 1.749 & $3.02[0.02]$ & 1.255 & 9.325 \\
\hline lnbrt_oilp $+(-1)$ & -4.996 & 1.881 & $-2.65[0.03]$ & -9.336 & -0.656 \\
\hline $\operatorname{brt}_{\text {bilp}}(-1)$ & -4.595 & 1.724 & $-2.67[0.03]$ & -8.571 & 0.620 \\
\hline$\Delta \operatorname{lnGDP}(-1)$ & 0.715 & 0.226 & $3.16[0.01]$ & 0.194 & 1.237 \\
\hline$\Delta \operatorname{lnwti\_ oilp}{ }^{+}$ & 0.815 & 0.387 & $2.11[0.07]$ & -0.776 & 1.709 \\
\hline$\Delta$ lnwti_oilp $+(-1)$ & -2.502 & 1.513 & $-1.65[0.14]$ & -5.992 & 0.988 \\
\hline$\Delta$ lnwti_oilp $^{+}(-2)$ & -2.502 & 0.934 & $-1.31[0.23]$ & -3.382 & 0.927 \\
\hline$\Delta \operatorname{lnwti}{ }^{\prime}$ oilp $^{+}(-3)$ & 0.766 & 0.646 & $1.19[0.27]$ & -0.724 & 2.223 \\
\hline$\Delta$ lnwti_oilp & 1.140 & 0.470 & $2.43[0.04]$ & 0.056 & 11.526 \\
\hline$\Delta \operatorname{lnwti}{ }^{\prime}$ oilp $^{-}(-1)$ & -3.510 & 1.190 & $-2.95[0.02]$ & -6.257 & -0.764 \\
\hline$\Delta \ln w$ ti_oilp- $(-2)$ & -1.654 & 1.085 & $-1.52[0.17]$ & -4.155 & 0.847 \\
\hline$\Delta \operatorname{lnwti}{ }^{2}$ oilp- $(-3)$ & -1.249 & 0.634 & $-1.97[0.08]$ & -2.710 & 0.213 \\
\hline$\Delta \operatorname{lnbrt} \_o i l p^{+}$ & -0.721 & 0.381 & -1.89 [0.09] & -1.598 & 0.157 \\
\hline$\Delta$ lnbrt_oilp ${ }^{+}(-1)$ & 2.102 & 1.438 & $1.46[0.18]$ & -1.213 & 5.418 \\
\hline$\Delta$ lnbrt_oilp ${ }^{+}(-2)$ & 0.946 & 0.903 & $1.05[0.33]$ & -1.135 & 3.028 \\
\hline$\Delta$ lnbrt_oilp ${ }^{+}(-3)$ & -0.665 & 0.625 & $-1.07[0.32]$ & -2.106 & 0.775 \\
\hline$\Delta$ lnbrt_oilp & -0.926 & 0.456 & $-2.03[0.07]$ & -1.976 & 0.125 \\
\hline$\Delta$ lnbrt_oilp-- $(-1)$ & 3.213 & 1.200 & $2.68[0.02]$ & 0.446 & 5.980 \\
\hline$\Delta$ lnbrt_oilp-- $(-2)$ & 1.568 & 1.061 & $1.48[0.18]$ & -0.878 & 4.015 \\
\hline$\Delta$ brt_oilp-- $(-3)$ & 1.046 & 0.614 & $1.70[0.13]$ & -0.370 & 2.462 \\
\hline \multicolumn{6}{|c|}{ Asymmetric tests and model diagnostics } \\
\hline$L_{w t i \_o i l p}^{+}$ & $2.411(0.00)$ & $\overline{L_{b r t \_o i l p}^{+}}$ & $-2.092(0.02)$ & & \\
\hline$L_{w t i \_o i l p}^{-}$ & $-2.215(0.00)$ & $L_{b r t \_o i l p}^{-}$ & $1.924(0.02)$ & & \\
\hline$W_{L R, \text { wti_oilp }}$ & $2.986(0.12)$ & $W_{L R, \text { brt_oil }}$ & $2.636(0.14)$ & & \\
\hline$W_{S R, w t i \_o i l p}$ & $11.45(0.01)$ & $W_{S R, \text { brt_oil }}$ & $12.24(0.00)$ & & \\
\hline$F_{\text {-PASS }}$ & 9.76 & & & 3.800 & 5.643 \\
\hline $\bar{R}^{2}$ & 0.83 & & & & \\
\hline$X_{S C}$ & $9.987(0.695)$ & $X_{\text {NORM }}$ & $0.562(0.76)$ & & \\
\hline$X_{H E T}$ & $1.419(0.23)$ & $X_{\text {RAMSEY }}$ & $1.442(0.34)$ & & \\
\hline
\end{tabular}

Note: Conf. interval = confidence interval. $\mathrm{L}^{+}$and $\mathrm{L}^{-}$denote estimated long-run asymmetric effects of oil prices: positive and negative partial sums, respectively, defined by $\hat{\beta}=-\hat{\lambda} / \hat{\rho}$.

$X_{S C}, X_{H E T}, X_{N O R M}$, and $X_{R A M S E Y}$ are serial correlation LM, heteroscedasticity, normality, and functional form tests, respectively.

$W_{L R, \text { wti_oilp }}$ and $W_{L R, \text { brt_oilp }}$ are the long-rung asymmetric $F$-stat modelled as: $-\hat{\lambda}_{1}^{+} / \hat{\rho}=$ $-\hat{\lambda}_{1}^{-} / \hat{\rho}$ and $-\hat{\lambda}_{2}^{+} / \hat{\rho}=-\hat{\lambda}_{2}^{-} / \hat{\rho}$, respectively.

$W_{S R \text {, wti_oilp }}$ and $W_{S R, \text { brt_oilp }}$ are the short-run asymmetric $F$-stat modelled as: $\sum_{j=0}^{q} \pi_{1}^{+}=\sum_{j=0}^{q} \pi_{1}^{-}$and $\sum_{j=0}^{q} \pi_{2}^{+}=\sum_{j=0}^{q} \pi_{2}^{-}$, respectively.

[] are the standard errors, and ( ) are the p-values. Critical value (5.07) with unrestricted intercept and unrestricted trend for $F_{\text {-pass, } 0.05, \mathrm{k}=3}$ obtained from Narayan et al. (2005).

In the case of Angola, Table 3b, the response of Angolan GDP to a positive change in oil prices $\left(L_{w t i_{\text {ooilp }}}^{+}=0.06\right.$ and $\left.L_{b r t_{-} \text {oilp }}^{+}=0.39\right)$ is distinctly not significant. In contrast, statistically significant long-run impacts of oil prices, in absolute term, are detected from the negative components $\left(L_{w t i_{-} \text {oilp }}^{-}=4.53\right.$ and $\left.L_{\text {brt_oilp }}^{-}=4.46\right)$, each at $1 \%$ level, respectively. Analytically, for Angola, a slump in oil price by $1 \%$ per barrel may result in aggregate economic downturn in the range of $4.46 \%$ to $4.53 \%$. This coefficient, which is rather large, raises a concern about the economic sustainability of the country when oil price is not favourable. This has an important signal for net oil-exporting economies, especially the developing member countries of the 
Organisation of Petroleum Exporting Countries (OPEC). They need to design an appropriate economic measure, which should specifically focus on economy diversification, for stabilization of the economy in the wake of fall in oil price.

Table 3b. Dynamic Asymmetric Estimation results for Angola

\begin{tabular}{|c|c|c|c|c|c|}
\hline \multirow{2}{*}{ Variable } & \multirow{2}{*}{ Coefficient } & \multirow{2}{*}{$\begin{array}{c}\text { Standard } \\
\text { error }\end{array}$} & \multirow{2}{*}{ T-ratio [Prob] } & \multicolumn{2}{|c|}{ 95\% Conf. interval } \\
\hline & & & & lower & upper \\
\hline Constant & 20.409 & 4.415 & $4.62[0.00]$ & 10.998 & 29.820 \\
\hline $\operatorname{lnGDP}(-1)$ & -0.851 & 0.184 & $-4.62[0.00]$ & -1.245 & -0.458 \\
\hline lnwti_oilp ${ }^{+}(-1)$ & 0.047 & 0.740 & $0.06[0.95]$ & -1.531 & 1.626 \\
\hline lnwti_oilp-(-1) & -3.858 & 1.264 & $-3.05[0.00]$ & -6.552 & -1.163 \\
\hline lnbrt_oilp+ $(-1)$ & 0.331 & 0.712 & $0.47[0.64]$ & -1.187 & 1.850 \\
\hline lnbrt_oilp- (-1) & 3.802 & 1.179 & $3.22[0.00]$ & 1.289 & 6.315 \\
\hline$\Delta \operatorname{lnGDP}(-1)$ & 0.640 & 0.174 & $3.67[0.00]$ & 0.268 & 1.011 \\
\hline$\Delta \operatorname{lnGDP}(-2)$ & 0.165 & 0.174 & $0.85[0.41]$ & -0.247 & 0.578 \\
\hline$\Delta \operatorname{lnGDP}(-3)$ & 0.266 & 0.205 & $1.29[0.22]$ & -0.172 & 0.704 \\
\hline$\Delta$ lnwti_oilp ${ }^{+}$ & 0.676 & 0.508 & $1.33[0.20]$ & -0.406 & 1.759 \\
\hline$\Delta$ lnwti_oilp ${ }^{+}(-1)$ & 0.131 & 0.512 & $0.26[0.80]$ & -0.959 & 1.222 \\
\hline$\Delta$ lnwti_oilp- & -0.594 & 0.942 & $-0.63[0.54]$ & -2.602 & 1.414 \\
\hline$\Delta$ lnwti_oilp- $(-1)$ & 3.648 & 1.068 & $3.42[0.00]$ & 1.372 & 5.924 \\
\hline$\Delta$ lnbrt_oilp ${ }^{+}$ & -0.309 & 0.494 & $-0.63[0.54]$ & -1.362 & 0.744 \\
\hline$\Delta$ lnbrt_oilp ${ }^{+}(-1)$ & -0.106 & 0.473 & $-0.22[0.83]$ & -1.114 & 902 \\
\hline$\Delta$ lnbrt_oilp & 0.455 & 0.911 & $0.50[0.63]$ & -1.488 & 2.399 \\
\hline$\Delta$ lnbrt_oilp-- $(-1)$ & -3.629 & 1.020 & $-3.56[0.00]$ & -5.803 & -1.454 \\
\hline \multicolumn{6}{|c|}{ Asymmetric tests and model diagnostics } \\
\hline$L_{w t i \_o i l p}^{+}$ & $0.056(0.95)$ & $L_{b r t \_o i l p}^{+}$ & $0.389(0.64)$ & & \\
\hline$L_{w t i \_o i l p}^{-}$ & $4.529(0.00)$ & $L_{\text {brt_oilp }}^{-}$ & $-4.463(0.00)$ & & \\
\hline$W_{L R, w t i \_o i l p}$ & $11.88(0.00)$ & $W_{L R, \text {,brt_oil }}$ & $10.98(0.01)$ & & \\
\hline$W_{S R, w t i \_o i l p}$ & $2.38(0.14)$ & $W_{S R_{,}, \text {brt_oil }}$ & $3.64(0.07)$ & & \\
\hline$F_{-}$PASS & 5.68 & & & 3.800 & 5.643 \\
\hline $\bar{R}^{2}$ & 0.56 & & & & \\
\hline$X_{S C}$ & $14.42(0.42)$ & $X_{N O R M}$ & $5.217(0.07)$ & & \\
\hline$X_{H E T}$ & $8.18(0.00)$ & $X_{R A M S E Y}$ & $4.992(0.02)$ & & \\
\hline
\end{tabular}

Note: See Table 3a for the description of items.

In order to verify the appropriateness of the estimated dynamic model, we judge the model on several diagnostic statistics provided by STATA software version 13, on model adequacy. These include the Jarque-Bera test on normality $\left(X_{n o r m}\right)$, Ramsey Reset LM test $\left(X_{R A S E Y}\right)$ for functional form, Serial correlation LM test $\left(X_{S C}\right)$ for autocorrelation, and Breusch-Pagan heteroskedasticity test $\left(X_{H E T}\right)$. These are presented in the lower panel of Table $3 \mathrm{a}$ and $3 \mathrm{~b}$. For Nigeria, the model passed all diagnostic tests suggesting error normality, absence of autocorrelation and parameter stability. For Angola, only $X_{S C}$ passed the test and the null hypothesis of serial correlation is rejected. However, $\bar{R}^{2}(56 \%)$ is considered to be adequate for model fit. Accordingly, the dynamics of oil price shocks is adequately specified.

The dynamic relationship between oil price (WTI) and GDP is further explored by studying the graphical dynamic multiplier effects, considering fully the asymmetric case of Eq. 7. The Figures show the dynamic effects of positive and negative changes of oil price (WTI). We observed from the figure that Nigerian economy responds quickly to changes in oil price than that of Angola. For Nigeria, the response to increase and decrease in oil price is obviously more rapid with equilibrium correction achieved in the beginning of the 2 nd year. However, the absolute effect of a decrease in oil price is larger than that of an increase on the country's economy. The gap in magnitude between positive and negative shocks in oil price diminishes 
very rapidly and disappears within a year. Thereafter, the gap turns opposite revealing that, when considering a longer time horizon, the effect of downwards deviations in oil price significantly dominates upwards deviations. More so, observing the growth of economy in Nigeria at quartile $1(25.4 \%)$ and quartile $3(26.3 \%)$, the country is likely to be more vulnerable to oil price fall than upper-income or middle-income net oil-exporting countries, in line with IMF report [20]. This finding raises a concern on how Nigerian economy would adjust to equilibrium after to 8 to 10 years of shock. This suggests that the impact of initial oil price increase was not immediately felt in the economy.
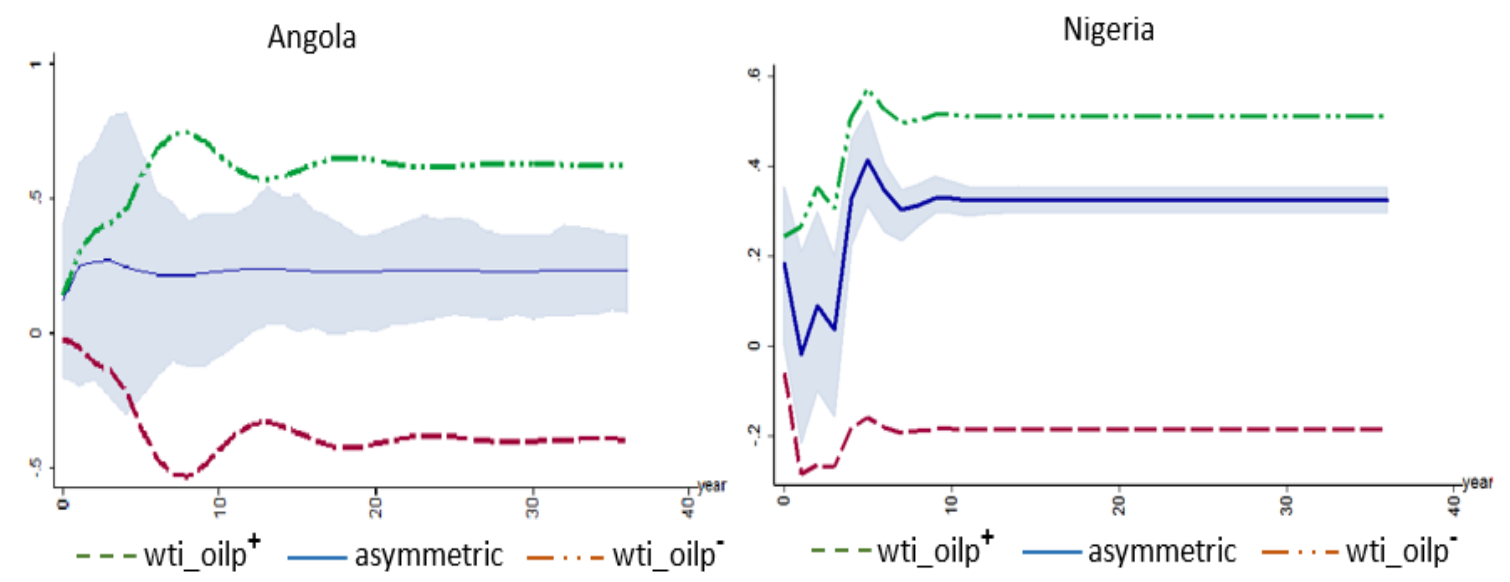

Dynamic multiplier effects of oil price (WTI) on GDP

For Angola, we noticed a very short-living response of economy to negative oil price shock. Though the response quickly spread, but stable adjustment to equilibrium occurred after the 10th year. Put differently, the dynamic multipliers revealed that Angolan economy is more sensitive and reacts faster towards equilibrium in slump periods than in boom periods. The influences of positive and negative oil price changes on Angola and Nigeria, strengthened our conclusion that the shocks are likely to be more felt by Nigeria especially when oil price falls. On this basis, currency devaluation to attract more foreign earning to support oil revenue and consequently boost the economy is a step to right direction. However, such action and application of expansionary monetary policy for stabilizing the economy to support oil revenue when oil price falls may have little effect. With the speculation that continued drop in oil price may reach between $\$ 5$ and $\$ 15$ (IMF [20]), this however means that the focus should specifically be on economic diversification.

\section{CONCLUSION}

In this study, we examined dynamic effect of oil price shocks on oil economy for net oilexporting countries, with particular reference to Angola and Nigeria. Recognizing shiftingregime in oil price, we adopted a dynamic Autoregressive Distributed Lag cointegration technique for the analysis to capture both long- and short-run asymmetric relationship between oil price and GDP growth, which traditional ARDL has been found to poorly detect. In addition, in oil price-growth literature, attention mostly focused on developed oil-exporting or -importing countries which leaves dearth of studies on developing countries whose oil price fluctuations may be more pronounced. This study contributes to literature in this aspect. In this paper, both the West Intermediate Texas and Brent oil prices were used as determinants of economic growth. The effect of West Intermediate Texas or Brent oil price, on economic growth is similar as expected. Nonetheless, the two prices were used for robustness purpose.

From the analysis, we found evidence for the presence of asymmetries both in the long-run and in the short-run for Angola, but only in the short-run for Nigeria. Regarding the short-run time horizon, the asymmetric coefficients were statistically significant, running from all the two oil 
prices examined towards the observed economies. However, there seem to exist important differences in the response of the economies to positive or negative changes of the oil prices. This is clearly shown in the dynamic multiplier effects explored. The differences show that oil price shocks is likely to be much felt by Nigeria than Angola especially in the oil price slump regime periods. On this basis, economic stabilizing policy enacted in the economy to support oil revenue shortfall may have little effect, with the speculation that continued drop in oil price may reach between US $\$ 5$ and US $\$ 15$ per barrel. This means that the focus should specifically be on economic diversification.

A more generalized analysis can be extended to all OPEC member countries for comparison of results, and if the effect of oil price shocks on high-income net oil-exporting countries and lowincomes would different, which is not captured in this present study. Nonetheless, the use of asymmetric ARDL model in this study contributes to the understanding of nonlinear nature of the variable, and its ability to lead to forecasting and efficient policymaking.

\section{ACKNOWLEDGEMENT}

We thank the participants, section four of the $4^{\text {th }}$ international conference on social sciences, organized by Nile University, Abuja, Nigeria, for their suggestions on the first draft of this paper presented at the conference.

\section{References}

Adedeji, A.N., Sidique, S.F., Abd Rahman, A. and Law, S.H., 2016. The role of local content policy in local value creation in Nigeria's oil industry: A structural equation modeling (SEM) approach. Resources Policy, 49, 61-73.

Andreopoulos, S., 2009. Oil matters: real input prices and U.S. unemployment revisited. The B.E. Journal of Macroeconomics, 9, 1-29.

Aliyu, A.J and Tijjani, S.M., 2015. Asymmetric cointegration between exchange rate and trade balance in Nigeria. Cogent Economics and Finance, 3, 1- 9.

Alley, I., Asekomeh, A., Mobolaji, H. and Adeniran, Y.A., 2014. Oil price shocks and Nigerian economic growth. European Scientific Journal, 10, 375-391.

Balke, N.S. and Fomby, T.B., 1997. Threshold cointegration. International Economic Review, 3, 627 - 645.

Benassy-Quere, A. Mignon V. and Penot A., 2007. China and the relationship between the oil price and the dollar. Energy Policy, 35, 5795-5805.

Brown, S.P.A., and Yücel, M. K., 2002. Energy Prices and Aggregate Economic Activity: An Interpretative Survey. Quarterly Review of Economics and Finance, 2, 193-208.

Caldara D.M.C. and Iacoviello, M. Mimeo: Federal Reserve Board, 2016.

CBN, 2015. Statistical Bulletin, Central Bank of Nigeria, Abuja, Nigeria.

Choudhry, T., Hassan, S.S. and Papadimitriou, F.I., 2014. UK imports, third country effect and the global financial crisis: Evidence from the asymmetric ARDL method. International Review of Financial Analysis, 32, 199 -208.

Dogrul, H.G. and Soytas, U., 2010. Relationship between oil prices, interest rate, and unemployment: Evidence from an emerging market. Energy Economics, 32, 1523-1528.

EIA. 2016. Energy Information Administration. Washington, DC.

Enders, W. and Siklos, P.L., 2001. Cointegration and Threshold Adjustment. Journal of Business and Economic Statistics, 19(2), 166-176.

Ewing, B.T. and Thompson, M.A., 2007. Dynamic cyclical comovement of oil prices with industrial production, consumer prices, unemployment, and stock prices. Energy Policy, 35, 5535-5540.

Gadea, M.D., Gómez-Loscos, A. and Montañés, A., 2016. Oil price and economic growth: A long story? Econometrics, 4, 1-28.

Ghalayini, L., 2011. Interaction between oil price and economic growth. Review of Middle East Economics and Finance, 13, 127-143. 
Gunu, U. and Abdulhakeem, A. K., 2010. Oil price shocks and the Nigeria Economy: A variance autoregressive (VAR) model. International Journal of Business and Management, 8, 15-39.

He, Y., Wang, S. and Lai, K.K., 2010. Global economic activity and crude oil prices: A cointegration analysis. Energy Economics, 32, 868 -876.

Ibrahim, M.H., and Chancharoenchai, K., 2014. How inflationary are oil price hikes? A disaggregated look at Thailand using symmetric and asymmetric cointegration models. Journal of the Asia Pacific Economy, 3, 409-422.

International Monetary Fund (IMF) Report, 2015. "IMF Executive Board Concludes 2015 Article IV Consultation with Iran". Available from: https://www.imf.org/en/News/Articles/2017/02/27/PR1765-IMF-Executive-BoardConcludes-2016-Article-IV-Consultation-with-the-Islamic-Republic-of-Iran. Retrieved: 6/12/2017.

Ishmael, O., Rivi, M.T. and Idisi, P., 2017. The Impact of Changes in Crude Oil Prices on Economic Growth in Nigeria: 1986 - 2015. Journal of Economics and Sustainable Development, 12, 78-89.

Ismail, S. and Babajide, N., 2015. Oil price shocks and Nigeria's Economic Activity: Evidence from ARDL Cointegration and VECM analysis. Available at SSRN: https://ssrn.com/abstract=2624004 or http://dx.doi.org/10.2139/ssrn.2624004. Accessed: 1/5/2018.

Jawa, M., 2013. Oil price volatility and its impact on economic growth in Pakistan. Journal of Finance and Economics, 4, $62-68$.

Kabiru, I.M, Saari, M.Y., Habibullah, M.S. and Utit, C., 2017. Measuring the economic impacts of recent oil price shocks on oil-dependent economy: evidence from Malaysia, Policy Studies, 1-19.

Kapetanios, G., Shin, Y. and Snell, A., 2006. Testing for cointegration in nonlinear smooth transition error correction models. Econometric Theory, 22, 279-303.

Katrakilidis, C. and Trachanas, E., 2012. What drives housing price dynamics in Greece: New evidence from asymmetric ARDL cointegration. Economic Modelling, 29, 1064 -1069.

Lardic, S. and Mignon, V., 2008. Oil prices and economic activity: Asymmetric cointegration approach. Energy Economics, 30, 847-855.

Law, S.H, Lee, W.C and Singh, N., 2017. Revisiting the finance-innovation nexus: Evidence from a non-linear approach. Journal of Innovation and Knowledge. DOI:10.1016/j.jik.2017.02.001. https://plu.mx/plum/a/? doi:10.1016/j.jik.2017.02.001.

Lescaroux, F. and Mignon, V., 2008. On the influence of oil prices on economic activity and other Macroeconomic and Financial Variables. Working paper of Centre d'Etudes Prospectives et d'Informations Internationales (CEPII) N0. 5 .

Mohaddes, K. and Pesaran, M.H., 2016. Oil Prices and the Global Economy: Is It Different This Time Around? International Monetary Fund Working Paper 16/210.

https://www.imf.org/external/pubs/ft/wp/2016/wp16210.pdf. Accessed: 17/12/2017.

Monesa, I and Qazi, L.T., 2015. The Effects of Oil Price Shocks on Economic Growth of Oil Exporting Countries: A Case of Six OPEC Economies.

https://www.imsciences.edu.pk/files/journals/Vol.\%205\%20No.\%201.\%20April\%202013/Paper\%20(5).pdf

Nagmi, M. and Aimer, M., 2016. The effects of fluctuations of oil price on economic growth of Libya. Energy Economics Letters, 3, 17-29.

Narayan, P.K., 2005. The saving and investment nexus for China: evidence from cointegration tests. Applied Economics, 37, 1979-1990.

Nikbakht, L., 2009. Oil prices and exchange rates: The case of OPEC. Business Intelligence Journal, 3, 83-92.

Oladosu, A.G., Leiby, P.N., Bowman, D.C, Uría-Martínez, R., and Johnson, M.M., 2018. Impacts of oil price shocks on the United States economy: A meta-analysis of the oil price elasticity of GDP for net oil-importing economies. Energy Policy, 115, 523-544.

OPEC, 2017. Annual Statistical Bulletin. http://www.opec.org/opec_web/en/publications/4140.htm. Accessed: $1 / 8 / 2018$.

Oyeyemi, A.M., 2013. The growth implications of oil price shock in Nigeria. Journal of Emerging Trends in Economics and Management Sciences, 4, 343-349.

Ovadia, J.S., 2016. Local content policies and petro-development in Sub-Sahara Africa: A comparative analysis. Resources Policy, 49, 20-30. 
Ovadia, J.S., 2014. Local content and natural resource governance: The cases of Angola and Nigeria. The Extractive Industries and Society, 1, 137-146.

Ovadia, J.S., 2012. The dual nature of local content in Angola's oil and gas industry: development vs. elite accumulation. Journal of Contemporary African Studies, 3, 395-417.

Pesaran M.H. and Shin Y., 1999. An autoregressive distributed lag modelling approach to cointegration analysis. In: Storm S(ed) Econometrics and Economic Theory in the 20th Century: The Ragnar Frisch Centennial Symposium, Chapter 11. Cambridge University Press, Cambridge.

Pesaran M.H., Shin Y. and Smith, R.J., 2001. Bounds testing approaches to the analysis of level relationship. Journal of Applied Econometrics 16, 289-326.

Psaradakis, Z., Sola, M., and Spagnolo, F., 2004. On Markov error-correction models, with an application to stock prices and dividends. Journal of Applied Econometrics, 19, 69-88.

Rafiq, S., Salim, R. and Bloch, H., 2009. Impact of crude oil price volatility on economic activities: An empirical investigation in the Thai economy. Resources Policy, 34, $121-132$.

Ratti, R.A. and Vespignani, J.L., 2015. OPEC and Non-OPEC oil production and global economy. Energy Economics, 50, $364-378$.

Salisu, A.A., Isah, K.O., Oyewole, O.J. and Akanni, L.O., 2017. Modelling oil price-inflation nexus: The role of asymmetries. Energy, 125, 97-106.

Sayed, M.A.A., 2010. The impact of oil prices on the economic growth and development in the MENA countries. In Proceedings of Middle East Economic Association (MEEA) 15 ${ }^{\text {th }}$ International Conference, Speyer, Germany.

Schorderet, Y., 2003. Asymmetric cointegration. Working Paper, Econometrics Department, University of Geneva. Available: https://core.ac.uk/download/pdf/7134653.pdf. Accessed: 8/12/2017.

Shin, Y., Yu, B., and Greenwood-Nimmo, M., 2013. Modelling asymmetric cointegration and dynamic multipliers in a nonlinear ARDL framework. In W. C. Horrace, \& S.C. Sickles (Eds.), Festschrift in honor of Peter Schmidt. New York: Springer Science and Business Media.

Umar, G. and Abdulhakeem, K.A., 2010. Oil price shocks and the Nigeria economy: A Variance Autoregresive (VAR) model. International Journal of Business and Management, 5(8), 39 - 51. 